\title{
Effects of adjustable and stationary fans with misters on core body temperature and lying behavior of lactating dairy cows in a semiarid climate
}

\author{
S. D. Anderson, ${ }^{*}$ B. J. Bradford,† J. P. Harner,ł C. B. Tucker,§ C. Y. Choi,\# J. D. Allen, ${ }^{*}$ L. W. Hall, ${ }^{*}$ \\ S. Rungruang, ${ }^{*}$ R. J. Collier, ${ }^{* 1}$ and J. F. Smith ${ }^{* 2}$ \\ *Department of Animal Sciences, University of Arizona, Tuscon 85721 \\ †Department of Animal Sciences and Industry, and \\ †Department of Biological and Agricultural Engineering, Kansas State University, Manhattan 66502 \\ §Department of Animal Science, University of California, Davis 95616 \\ \#Department of Agricultural and Biosystems Engineering, University of Arizona, Tucson 85721
}

\section{ABSTRACT}

Cows readily seek shade to reduce solar heat load during periods of high ambient temperature. Typically, auxiliary cooling systems are oriented to maximize cooling for shaded cows. However, when a shade structure is oriented north-south, stationary fan and mister cooling systems are unable to track shade as the sun's angle shifts throughout the day, and thus can become ineffective. The FlipFan Dairy Cooling System (Schaefer Ventilation Equipment, Sauk Rapids, $\mathrm{MN}$ ) employs fans and misters that follow shade and compensate for wind speed by rotating on a horizontal axis. Multiparous, lactating Holstein cows $(\mathrm{n}=144)$ on a commercial dairy in Arizona were cooled by a fixed system comprised of stationary fans and misters acting as control or the adjustable FlipFan operated for $16.5 \mathrm{~h} / \mathrm{d}(0830$ to $0100 \mathrm{~h})$. Core body temperatures (CBT) of 64 cows (4 pens/treatment; 8 cows/pen; $6 \mathrm{~d}$ ) and lying behavior of 144 cows (4 pens/treatment; 18 cows/pen; 5 d) were collected by intravaginal and leg data loggers, respectively. Cows were balanced by milk production, blocked by days in milk, and randomly assigned to pen within block. Pen was the experimental unit. In a second experiment, isothermal maps were developed using a fixed system of thermal data loggers arranged in the shaded areas of the pens at different times of day and were analyzed for differences in the temperature-humidity index (THI) achieved by each cooling treatment. Ambient conditions consisted of a mean temperature of $33.0^{\circ} \mathrm{C}$, mean relative humidity of $40.3 \%$, and mean THI of 80.2. Mean 24-h CBT for FlipFan was lower than control (38.9 vs. $39.1 \pm$ $0.04^{\circ} \mathrm{C}$ ). A treatment $\times$ time interaction was observed in which CBT of FlipFan was $0.4^{\circ} \mathrm{C}$ lower than control

Received November 21, 2012.

Accepted April 9, 2013.

${ }^{1}$ Corresponding author: rcollier@ag.arizona.edu

${ }^{2}$ Deceased. from 0600 to $0800 \mathrm{~h}$ and 1500 to $1600 \mathrm{~h}$. Cows cooled by FlipFan spent more time lying down compared with those cooled by control (9.5 vs. $8.6 \mathrm{~h} / \mathrm{d})$. Cows under FlipFan had more frequent lying bouts than did those under control (12.8 vs. 10.7 bouts/d). Lower CBT and decreased standing time are consistent with the findings of other studies when ambient heat load was reduced. In the second experiment, the FlipFan system achieved a lower THI in the morning and evening (5.9 and $1.7 \%$, respectively), and the THI also tended to be $0.8 \%$ lower in the afternoon compared with that of control. Results indicate that FlipFan is more effective than a stationary fan and mister system at decreasing CBT, increasing lying time and bouts, and providing a more desirable microenvironment for cows throughout the day in a semiarid environment.

Key words: heat stress, adjustable fan, body temperature, lying behavior

\section{INTRODUCTION}

The ability of dairy cattle to maintain high levels of milk production is dependent on genetic, environmental, and management factors (Purwanto et al., 1990). Heat stress prevents dairy cattle from meeting their genetic potential for milk production, reproductive performance, and economic efficiency (Buffington et al., 1981; Kadzere et al., 2002). The increase in body temperature associated with heat stress directly affects gene expression and the biochemical pathways that regulate the rate of milk synthesis in the mammary gland (Collier et al., 2006). Indirectly, the increase in body temperature causes reductions in DMI and alters postabsorptive metabolism and nutrient partitioning (Rhoads et al., 2009). Consequently, heat stress has a profound negative effect on the profitability of dairy operations. St-Pierre et al. (2003) estimated that decreased performance, decreased reproduction rates, and increased mortality rates caused by heat stress led to $\$ 897$ million to $\$ 1.5$ billion annually in economic losses to the United States dairy industry. 
Aggressive selection for beneficial production traits in dairy cows over the past several decades has greatly improved milk yield per cow. It has been demonstrated, however, that milk yield is positively correlated with metabolic heat production (Purwanto et al., 1990; Kadzere et al., 2002; West, 2003). As a result, the highproducing dairy cow is more susceptible to the detrimental effects of heat stress. Previously, a temperaturehumidity index (THI) of 72 was widely accepted as the point at which dairy cows become heat-stressed. Recently, however, Zimbelman et al. (2009) re-evaluated this assumption and determined the threshold at which modern lactating cows enter heat stress to be a THI of 68 . This lowering of the heat-stress threshold has amplified the importance of cooling cows during hot weather.

Cows will actively seek shade to reduce solar heat load when ambient temperatures and solar radiation are high (Armstrong, 1994; Tucker et al., 2008). Collier et al. (1981) determined that cows with access to shade have lower rectal temperatures because the reduced solar heat load enabled them to better use sensible routes of heat loss. As ambient temperature increases and approaches core body temperature (CBT), the ability of cows to dissipate heat is compromised. To compensate, increased respiration and sweating increase evaporative heat loss. If other mechanisms cannot overcome heat gain, then CBT increases (Brown-Brandl et al., 2005).

Whereas providing cows with access to a simple shade structure alone has been shown to improve milk production and reproductive performance (RomanPonce et al., 1977), contemporary research has revealed the importance of providing additional cooling. Igono et al. (1987) reported that cows with shade and cooled by fans and spray produced $2 \mathrm{~kg} / \mathrm{d}$ more than cows under shade alone. Similarly, Correa-Calderon et al. (2004) observed that cows with access to shade alone registered higher rectal temperatures than shaded cows cooled with spray and fans or Korral Kool systems (Korral Kool Inc., Mesa, AZ). It has also been observed that cows prefer shade over sprinklers and ambient conditions but show no preference between sprinklers and ambient conditions, despite the ability of sprinklers to reduce heat load more efficiently (Schütz et al., 2011). Furthermore, the preference for shade apparently increases with higher ambient temperature.

Cows are motivated to lie down 12 to $13 \mathrm{~h} / \mathrm{d}$ (Jensen et al., 2005). Lying time decreases in warmer ambient conditions (Zähner et al., 2004; Tucker et al., 2008; Schütz et al., 2010), although the latter change is not seen in studies with a narrow temperature range (Reich et al., 2010). Spending more time standing may allow cows to maximize effective surface area for sensible and insensible heat loss from the body surfaces, reduce heat conducted from a warm lying surface, or increase the efficiency of respiration. Daily (24-h) lying time does not change with provision of shade alone (Kendall et al., 2006; Tucker et al., 2008); perhaps because insufficient shade per cow was available to allow animals to simultaneously lie down in the areas provided. Indeed, lying directly under the shade was rare in these experiments. However, changes in lying time may provide insight into effectiveness of a given cooling system when larger shades are provided, such as in dry or feedlots (Mitlöhner et al., 2001).

The FlipFan Dairy Cooling System (Schaefer Ventilation Equipment, Sauk Rapids, MN) couples fans and misters with shade throughout the entire day by rotating along a horizontal axis to compensate for the angle of the sun and wind speed. A previous version of this technology employed shade-tracking fans and misters oscillating along a vertical axis (Shade Tracker; Advanced Dairy Systems LLC, Chandler, AZ). That system was limited by the fact that cows were only in the arc of the cooling zone for a portion of the time during each rotation of the fans. The FlipFan system enables cows to remain in the cooling zone as they follow the shade throughout the day.

Our objective was to evaluate the effect of a stationary fan and mister cooling system and the FlipFan Dairy Cooling System on CBT, resting behavior, and the cow's microenvironment. We hypothesized that the FlipFan system is more capable of reducing heat stress by providing more uniform cooling throughout the day as compared with a stationary fan and mister system.

\section{MATERIALS AND METHODS}

\section{Experimental Design}

Two experiments were conducted on a commercial dairy farm (Figure 1) in Buckeye, Arizona, in August 2011. Multiparous, lactating Holstein cows $(\mathrm{n}=144$; milk production $=30.5 \pm 0.20 \mathrm{~kg} / \mathrm{d} ; \mathrm{DIM}=125 \pm 4.9$ d) were housed in dry-lot corrals (18 cows monitored/ pen). A shade structure (Table 1), oriented north-south, was located in the center of each pen. Shade structures were equipped with either of 2 cooling systems: the stationary fan and mister system, acting as the control (CTRL) and composed of fans and misters remaining in a fixed position facing eastward, or the adjustable FlipFan Dairy Cooling System (FLFN). Both cooling systems were installed below the western edge of the shade structures. Fans of both cooling systems $(0.9 \mathrm{~m}$ in diameter) were spaced at $2.54 \mathrm{~m}$ (center-to-center) and operated with a $375-\mathrm{W}$ motor for $16.5 \mathrm{~h} / \mathrm{d}$. Both 
cooling systems were programmed to turn on at 0830 $\mathrm{h}$ and turn off at $0100 \mathrm{~h}$. The selected operating times were set to provide cooling for cows during the hottest times of day while maximizing water availability. Two mister nozzles affixed to the front of each fan in both cooling systems ejected water continuously at $1.25 \mathrm{~L} /$ min per fan at $1.52 \mathrm{MPa}(220 \mathrm{psi})$ into the airstream. Pens were equipped with feedline soakers that operated for 45 min after each milking. Cows were fed at 0530 and $1630 \mathrm{~h}$ each day. Cows were milked 3 times/d in CTRL at 0200,1000 , and $1800 \mathrm{~h}$ and in FLFN at 0300, 1100, and 1900 h. Fans and misters were used in holding pens for both treatment groups. Cows spent $45 \mathrm{~min}$ away from their respective pens during each milking period.

Vaginal temperatures were collected from a subset of 64 multiparous, lactating Holstein cows (milk production $=30.2 \pm 0.23 \mathrm{~kg} / \mathrm{d} ; \mathrm{DIM}=123 \pm 7.2 \mathrm{~d}$ ) allotted to pens (4 pens/treatment; 8 cows monitored/pen) equipped with CTRL or FLFN in a completely randomized design. At the start of the study, mean milk production and DIM of 32 cows cooled by FLFN were $30.6 \pm 0.33 \mathrm{~kg} / \mathrm{d}$ and $122 \pm 10.3 \mathrm{~d}$, respectively. Mean milk production and DIM for 32 cows cooled by CTRL were $29.7 \pm 0.29 \mathrm{~kg} / \mathrm{d}$ and $123 \pm 10.3 \mathrm{~d}$, respectively.

Lying behavior of 144 multiparous, lactating Holstein cows (milk production $=30.5 \pm 0.20 \mathrm{~kg} / \mathrm{d} ; \mathrm{DIM}=125$ $\pm 4.9 \mathrm{~d}$ ) allotted to pens (4 pens/treatment; 18 cows/ pen) was measured. Mean milk production and DIM of the 72 cows cooled by FLFN were $31.3 \pm 0.23 \mathrm{~kg} / \mathrm{d}$ and $126 \pm 6.8 \mathrm{~d}$, respectively. Mean milk production and DIM for 72 cows cooled by CTRL were $29.6 \pm 0.29$ $\mathrm{kg} / \mathrm{d}$ and $123 \pm 7.2 \mathrm{~d}$, respectively.

On $\mathrm{d} 5$ and 7 of experiment 1, a second experiment used 2 unoccupied pens to generate isothermal maps of the cooling provided by each system. In each pen, a grid of 25 thermal data loggers, modeled after the procedures of Ortiz et al. (2010b), was used in the absence of cows for each of 3 periods within a day (morning, afternoon, and evening) to assess the microenvironment provided by each of the cooling systems. All data loggers were affixed to PVC stanchions $1 \mathrm{~m}$ above the ground and distributed throughout the shaded area depending on the position of the shadow at the beginning of each period and its predicted movement over each 2-h period. The spacing between data loggers represented

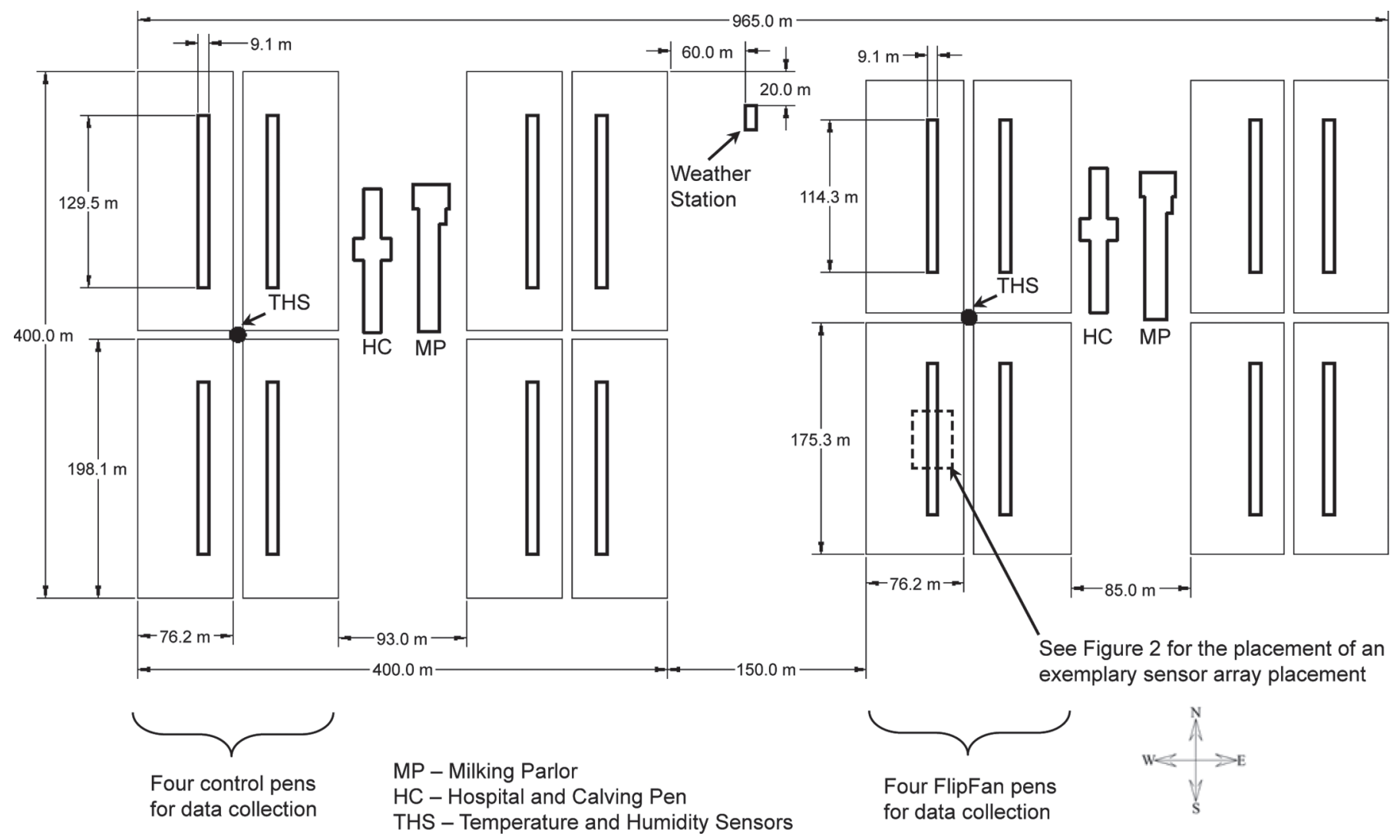

Figure 1. Detailed map of the experimental site on a commercial dairy farm in Buckeye, Arizona $\left(33^{\circ} 23^{\prime} 50^{\prime \prime} \mathrm{N}, 112^{\circ} 30^{\prime} 40^{\prime \prime} \mathrm{W}\right.$; elevation $=$ $277 \mathrm{~m})$. 
Table 1. Pen and shade dimensions and stocking density information

\begin{tabular}{|c|c|c|}
\hline \multirow[b]{2}{*}{ Item } & \multicolumn{2}{|c|}{ Treatment } \\
\hline & Control $^{1}$ & FlipFan $^{2}$ \\
\hline Mean cows/pen (n) & 280 & 246 \\
\hline Head locks/pen (n) & 288 & 256 \\
\hline Pen dimensions (m) & $76.2 \times 198.1$ & $76.2 \times 175.3$ \\
\hline Pen area $\left(\mathrm{m}^{2}\right)$ & $15,095.2$ & $13,357.9$ \\
\hline Pen area/cow $\left(\mathrm{m}^{2}\right)$ & 53.9 & 54.3 \\
\hline Shade structure (m) & $9.1 \times 129.5 \times 4.1$ & $9.1 \times 114.3 \times 3.7$ \\
\hline Shade area $\left(\mathrm{m}^{2}\right)$ & $1,178.5$ & $1,040.1$ \\
\hline Shade area/cow $\left(\mathrm{m}^{2}\right)$ & 4.2 & 4.2 \\
\hline Fans/shade structure (n) & 50 & 45 \\
\hline Bays/shade structure (n) & 17 & 15 \\
\hline Fans/bay (n) & $3^{3}$ & 3 \\
\hline Fan spacing (center-to-center; m) & 2.54 & 2.54 \\
\hline
\end{tabular}

the width of the shade structures and was shifted to the west or east with respect to the location of the shadow (Figure 2). This experiment did not take place at the same time as CBT and lying behavior data collection.

\section{Data Collection}

Lying behavior was determined by HOBO Pendant $\mathrm{G}$ data loggers (Onset Computer Corp., Bourne, MA) attached to the medial side of the cannon of either the right or left hind leg, recording angles on 3 different axes at 30-s intervals (Ledgerwood et al., 2010) for $5 \mathrm{~d}$. These data were edited; sole single or double (1-2) intervals of lying or standing were deleted from the data set, as were those where cattle switched the side they were lying on (left vs. right) within three 30 -s intervals. Leg data loggers were also attached $1 \mathrm{~d}$ before the start of data collection. Lying behavior and CBT data were collected simultaneously, but leg data loggers were removed $1 \mathrm{~d}$ earlier due to limited memory capacity.

Vaginal temperatures were obtained using HOBO U12 stainless data loggers (Onset Computer Corp.attached to blank controlled internal drug-releasing devices (Pfizer Animal Health, New York, NY) recording temperature at 5-min intervals for $6 \mathrm{~d}$ (Hillman et al., 2005; Ortiz et al., 2010a, 2010b, 2011). To allow cows to acclimate, all data loggers were inserted $1 \mathrm{~d}$ before the data collection period.

Ambient dry-bulb temperature and relative humidity (RH) were recorded continuously for the duration of the study by HOBO U23 Pro v2 data loggers (Onset Computer Corp.) placed in solar radiation shields at 2 locations on the farm away from the shade structures and cooling systems (Figure 1). Hourly wind speeds and direction were also recorded by a weather station located on site (Figure 1). Additionally, BCS and loco- motion scores were recorded as cows returned from the parlor in the morning.

For the isothermal mapping experiment, $25 \mathrm{HOBO}$ U23 Pro v2 and HOBO Pro H8 data loggers (Onset Computer Corp.) recorded dry-bulb temperature and $\mathrm{RH}$ of the shaded area of the pen at 5-min intervals during 3 separate time periods: morning (1000-1200 h), afternoon (1400-1600 h), and evening (1800-2000 h). Mapping data was collected simultaneously for both cooling systems during each time period on d 5 and 7 of experiment 1. Mean THI was calculated and isothermal maps were generated based on mean temperature readings in Surfer 8 (Golden Software Inc., Golden, CO) software.

\section{Statistical Analysis}

Vaginal temperature and resting behavior data were assessed using a least squares means analysis as a completely random design using the MIXED procedure for repeated measures of SAS (version 9.2, SAS Institute Inc., Cary, NC), with pen considered to be the experimental unit and included as the random term. Compound symmetry covariance structures were used to model repeated measures over time, and means and partitioning were generated with the LSMEANS and PDIFF options. Significance was declared with a $P$ value of $<0.05$, and trends were declared with a $P$-value between $>0.05$ and $<0.10$.

Mean hourly ambient air temperature and $\mathrm{RH}$ were considered as the ambient conditions. Mean hourly THI was also calculated using the formula THI $=(9 / 5 \times$ $\left.T_{\mathrm{db}}+32\right)-[0.55-(0.55 \times \mathrm{RH} / 100)] \times\left[\left(9 / 5 \times T_{\mathrm{db}}\right.\right.$ $+32)-58]$, where $T_{\mathrm{db}}$ is dry-bulb temperature $\left({ }^{\circ} \mathrm{C}\right.$; Correa-Calderon et al., 2004; Zimbelman et al., 2009). Vaginal temperatures were used to determine mean 

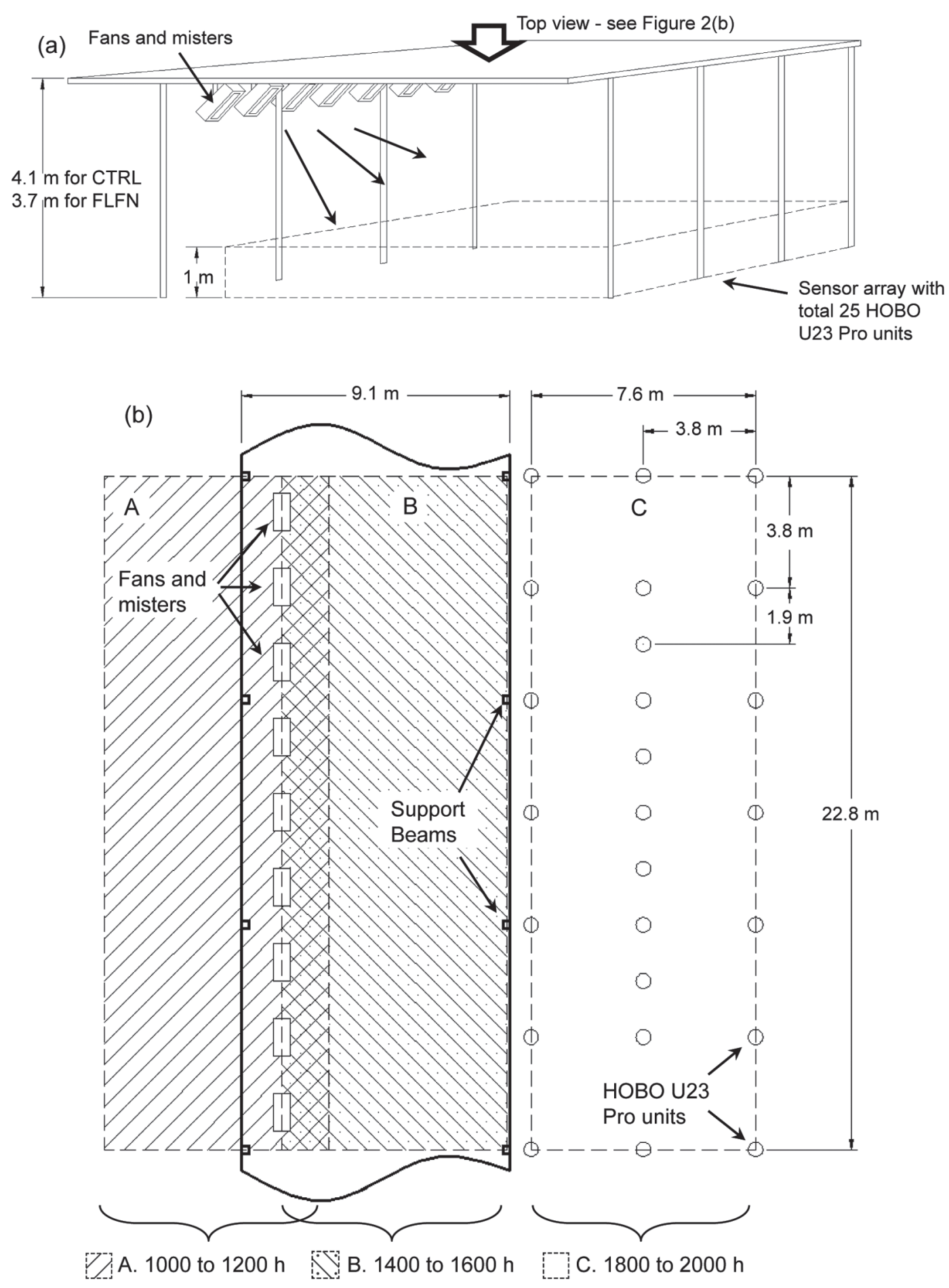

Figure 2. (a) Schematic of the experimental setup under the shade structure, and (b) 3 placements of the sensor array (A, B, and C) based on the shaded area at different times of the day, and detailed locations of the individual sensor units. CTRL $=$ control; FLFN $=$ FlipFan Dairy Cooling System (Schaefer Ventilation Equipment, Sauk Rapids, MN). HOBO U23 Pro units were from Onset Computer Corp. (Bourne, MA).

24-h CBT and mean hourly CBT. In addition, CBT data were used to determine the duration of time cows maintained a CBT above or below various temperatures each day.
Lying behavior data were summarized by analyzing the angles recorded by the leg data loggers and then calculating the total time and number of lying bouts for each cow. Cows observed to be lame (locomotion score 
$\geq 3 ; \mathrm{n}=2$ ) or that were relocated to the hospital pen during the study $(\mathrm{n}=2)$ were excluded from the final data analysis.

\section{RESULTS}

Mean dry-bulb temperature for the duration of the study was $33.0 \pm 0.75^{\circ} \mathrm{C}$ (Figure 3). Mean hourly dry-bulb temperatures ranged from $28.1^{\circ} \mathrm{C}$ at 0500 and $0600 \mathrm{~h}$ to $38.5^{\circ} \mathrm{C}$ at $1500 \mathrm{~h}$. Mean RH was $40.3 \pm$ $1.78 \%$; hourly RH ranged between $28.4 \%$ at $1400 \mathrm{~h}$ and $53.1 \%$ at 0500 and $0600 \mathrm{~h}$. Mean THI was calculated to be $80.2 \pm 0.59$ for the duration of the study and no differences were detected between the 2 recording stations. Mean hourly THI ranged from 76.3 at 0500 and $0600 \mathrm{~h}$ to 84.4 at $1500 \mathrm{~h}$. Ambient conditions under the shade structures were not recorded. Mean $( \pm \mathrm{SD})$ wind speed was $4.5 \pm 1.9 \mathrm{~m} / \mathrm{s}$. Overall wind direction was west-southwest during the study, yet wind speed and direction varied greatly throughout the study.

Cows cooled by FLFN had a mean 24-h CBT of 38.9 $\pm 0.04^{\circ} \mathrm{C}$, which was lower $(P<0.01)$ than that of CTRL-cooled cows $\left(39.1 \pm 0.04^{\circ} \mathrm{C}\right)$. A treatment $\times$ time interaction $(P<0.001)$ was detected for CBT (Figure 4). The greatest treatment effects on CBT $(P$ $<0.001$ ) occurred from 0600 to $0800 \mathrm{~h}$ and 1500 to $1600 \mathrm{~h}$, during which time mean hourly CBT was $0.4^{\circ} \mathrm{C}$ lower for cows cooled by FLFN. From 1800 to 1900 $\mathrm{h}$ and 2300 to $0300 \mathrm{~h}$, mean hourly CBT of cows in both treatments did not differ; however, mean hourly CBT was lower for cows under FLFN treatment at all times of day except from 0000 to $0300 \mathrm{~h}$, when CBT of CTRL-cooled cows tended to be lower $(P<0.10)$. Mean hourly CBT was highest at $0800 \mathrm{~h}$ for both treatments, reaching $39.7^{\circ} \mathrm{C}$ for CTRL-cooled cows and $39.3^{\circ} \mathrm{C}$ for FLFN-cooled cows. Immediately following this peak, CBT of cows in both treatments began to decrease until $1100 \mathrm{~h}$ for CTRL-cooled cows $\left(38.7^{\circ} \mathrm{C}\right)$ and $1200 \mathrm{~h}$ for FLFN-cooled cows $\left(38.5^{\circ} \mathrm{C}\right)$. The CBT of cows in both treatments increased as the afternoon progressed and ambient temperature increased. An increase in CBT was also observed immediately after the cooling systems were turned off at $0100 \mathrm{~h}$.

The length of time that the cows registered a CBT within a specified temperature interval also differed according to treatment $(P<0.05$; Table 2$)$. Cows cooled by FLFN remained below $38.6^{\circ} \mathrm{C}$ longer than CTRLcooled cows (335.4 vs. $174.6 \pm 28.20 \mathrm{~min} / \mathrm{d}$ ). Conversely, CTRL-cooled cows had a CBT above $38.6^{\circ} \mathrm{C}$ for a longer time $(1,265.4$ vs. $1,104.6 \pm 28.20 \mathrm{~min} / \mathrm{d})$. Cows cooled by FLFN also registered a CBT greater than $38.9,39.2,39.4$, and $39.7^{\circ} \mathrm{C}$ for a shorter amount of time than cows cooled by CTRL.

Mean locomotion score assessed for all cows was 1.06 \pm 0.02 . Cows cooled by FLFN spent approximately $1 \mathrm{~h}$ more each day (9.5 vs. $8.6 \pm 0.13 \mathrm{~h} / \mathrm{d}$ ) lying down than did cows cooled by CTRL $(P<0.001)$. Furthermore, cows cooled by FLFN had more $(P<0.001)$ lying bouts

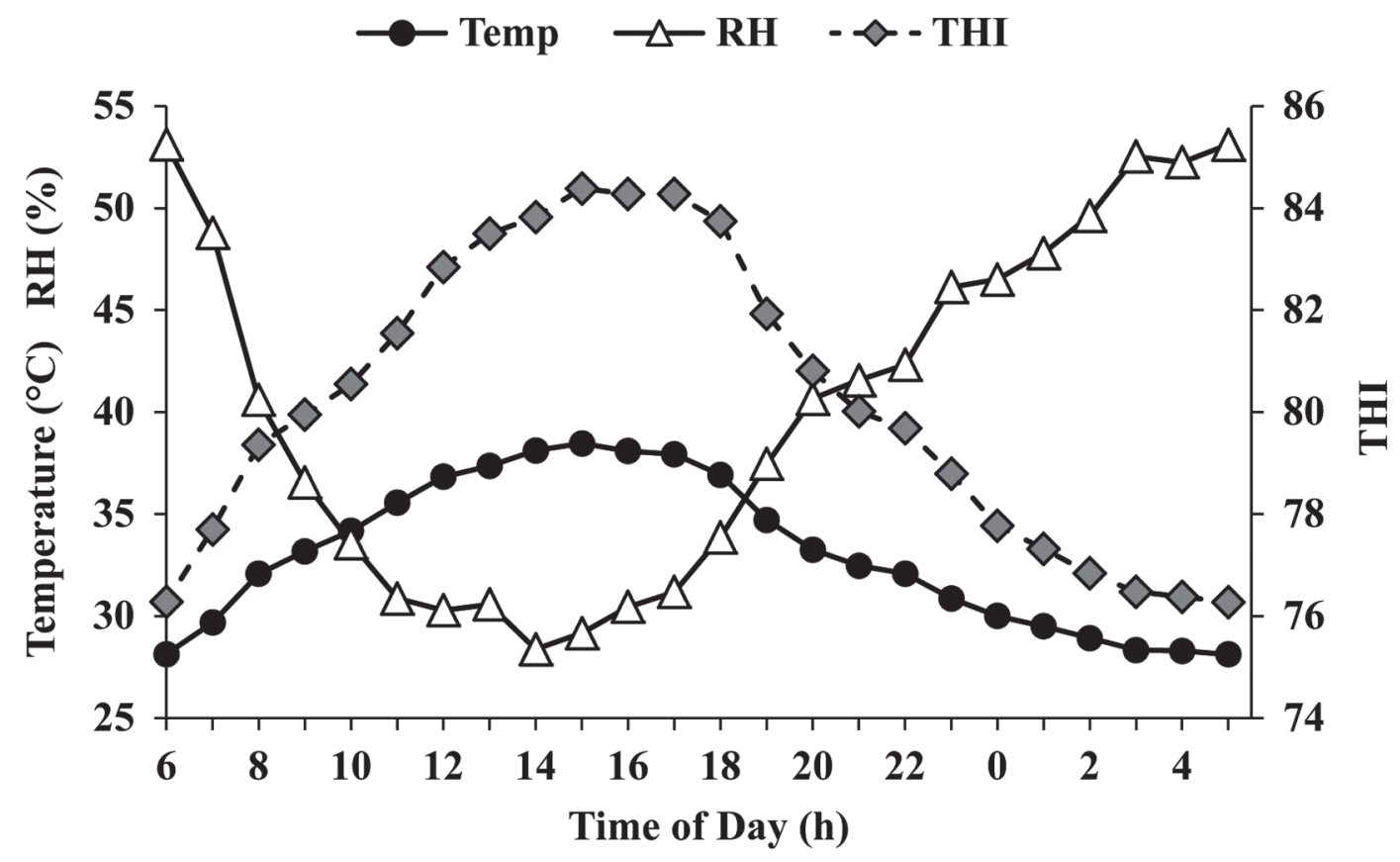

Figure 3. Mean hourly ambient temperature (Temp; $\left.{ }^{\circ} \mathrm{C}\right)$, relative humidity $(\mathrm{RH}, \%)$, and temperature-humidity index (THI). Pooled SEM $=0.15,0.36$, and 0.12 for temperature, $\mathrm{RH}$, and THI, respectively. 
Table 2. Duration of time core body temperature (CBT) of lactating Holstein cows remained above or below various temperatures cooled by stationary fans and misters or adjustable FlipFan Dairy Cooling System

\begin{tabular}{|c|c|c|c|c|}
\hline \multirow[b]{2}{*}{$\mathrm{CBT}\left({ }^{\circ} \mathrm{C}\right)$} & \multicolumn{2}{|c|}{ Duration $(\mathrm{h} / \mathrm{d})$} & \multirow[b]{2}{*}{ SEM } & \multirow[b]{2}{*}{$P$-value } \\
\hline & Control $^{1}$ & FlipFan $^{2}$ & & \\
\hline$<38.6$ & 2.91 & 5.59 & 0.47 & $<0.001$ \\
\hline$>38.6$ & 21.09 & 18.41 & 0.47 & $<0.001$ \\
\hline$>38.9$ & 12.74 & 9.90 & 0.57 & $<0.01$ \\
\hline$>39.2$ & 6.70 & 4.61 & 0.48 & $<0.01$ \\
\hline$>39.4$ & 2.91 & 1.79 & 0.29 & $<0.05$ \\
\hline$>39.7$ & 0.91 & 0.51 & 0.12 & $<0.05$ \\
\hline
\end{tabular}

${ }^{1}$ Stationary fans and misters.

${ }^{2}$ FlipFan Dairy Cooling System, Schaefer Ventilation Equipment, Sauk Rapids, Minnesota.

for each day $(12.8$ vs. $10.7 \pm 0.10)$. A treatment $\times$ time interaction was also detected for hourly lying time $(P$ $<0.001$; Figure 5).

Isothermal maps (Figures 6 to 8 ) show the mean THI of the shaded areas for FLFN and CTRL. In the morning, ambient THI was 80.6. The morning THI in the shaded area for FLFN was lower and cooled the shaded area to a mean THI of 74.6 compared with the 79.3 that CTRL achieved during this time $(P<0.001$; Figure $9)$. In the afternoon (1400-1600 $\mathrm{h}$ ), the mean ambient THI was 84.0. The FLFN system tended to achieve a lower THI $(P<0.10)$ than CTRL $(76.0$ vs. 76.6$)$. Mean THI in the evening (1800-2000 h) was 81.3. The FLFN system reduced the THI of the shaded area to 75.6, whereas the CTRL system cooled the shaded area to $76.8(P<0.001)$ during the same time. The coolest region of the shaded area used in both treatments was located on the eastern edge of the shadow. Maps of the CTRL areas show that the range of THI values during all the testing periods was larger than the range shown by the FLFN maps. That is, the maps for the FLFN-treated pens exhibit a more uniform distribution of cooling with an intermediate range of THI values compared with CTRL.

\section{DISCUSSION}

Under the ambient conditions recorded, cows would be subjected to continuous moderate heat stress without supplemental cooling throughout the duration of

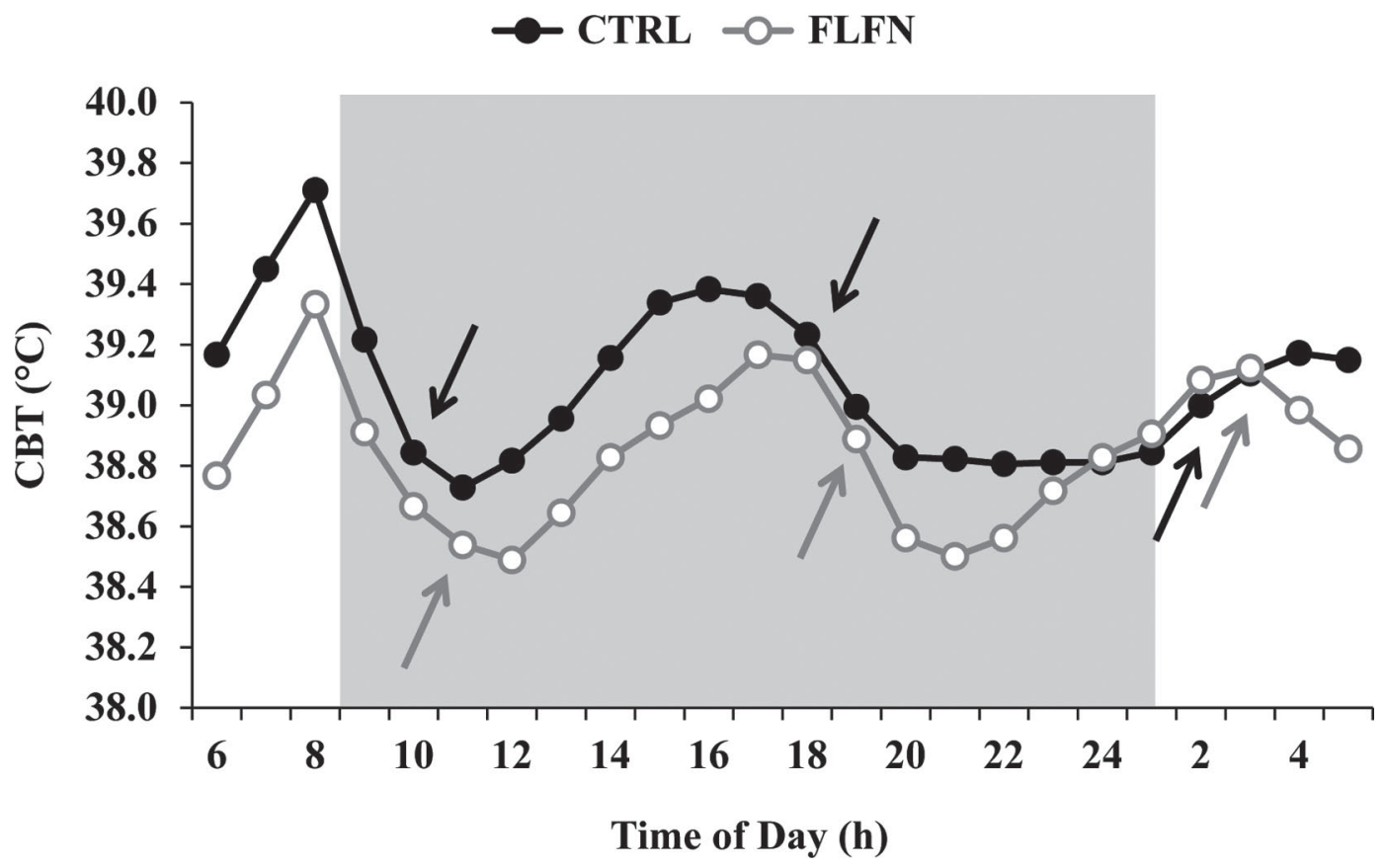

Figure 4. Mean hourly core body temperature (CBT) of lactating Holstein cows cooled by stationary fans and misters (CTRL) or adjustable FlipFan Dairy Cooling System (FLFN; Schaefer Ventilation Equipment, Sauk Rapids, MN). The shaded region represents cooling system operating time. Arrows denote milking times for each treatment. Treatment by time interaction $=P<0.001 ;$ pooled SEM $=0.06$. 


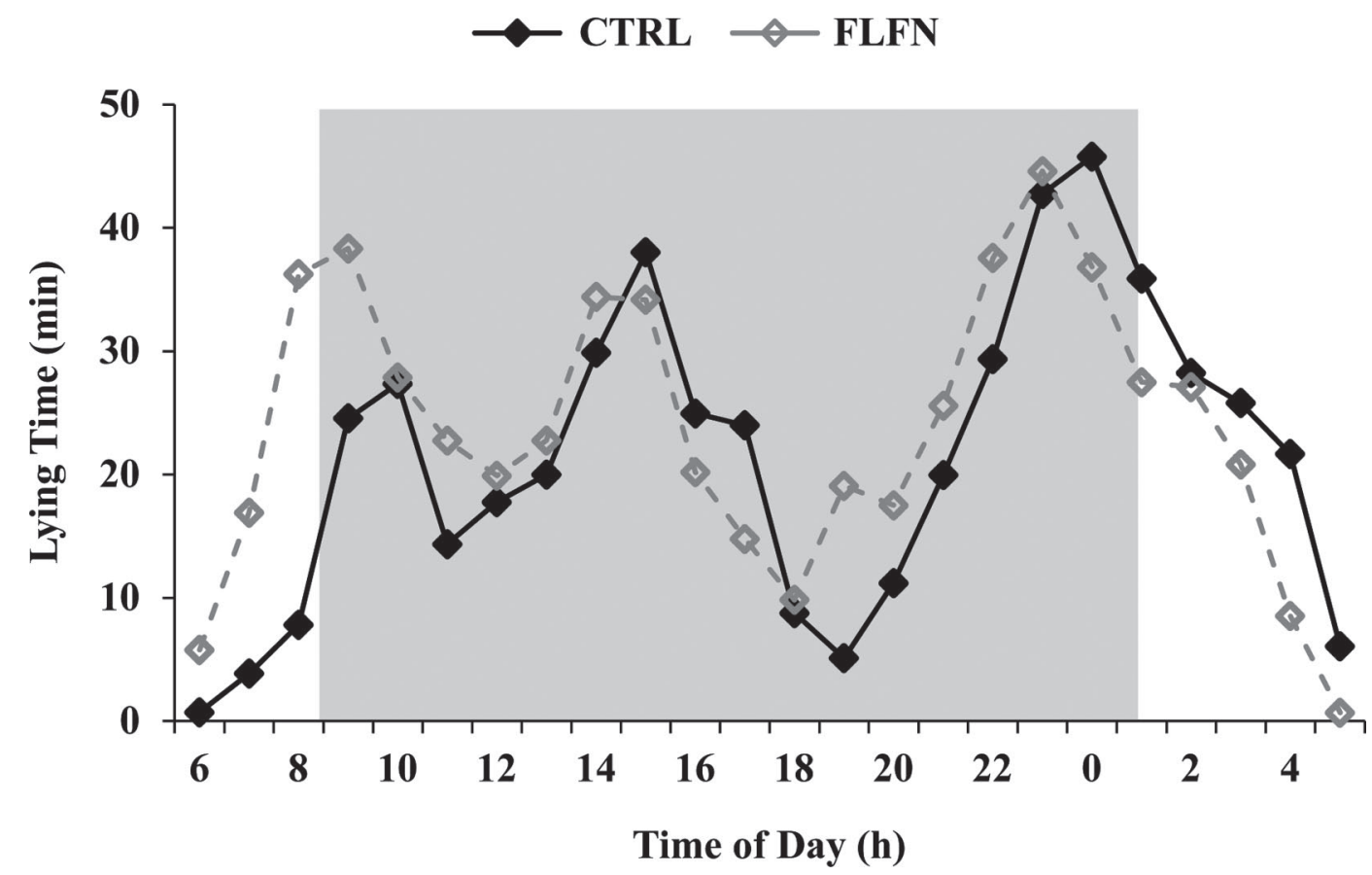

Figure 5. Mean hourly lying time of lactating Holstein cows cooled by stationary fans and misters (CTRL) or adjustable FlipFan Dairy Cooling System (FLFN; Schaefer Ventilation Equipment, Sauk Rapids, MN). Shaded region represents cooling system operating time. Treatment by time interaction $=P<0.001 ;$ pooled $\mathrm{SEM}=2.72$.

the study. Dry-bulb temperature, RH, and THI each followed typical diurnal rhythms. Ambient temperature and THI were lowest from 0500 to $0600 \mathrm{~h}$ and peaked in the afternoon at $1500 \mathrm{~h}$. Conversely, RH was generally inversely related to ambient temperature and THI. Mean RH was highest in the morning from 0500 to $0600 \mathrm{~h}$ and lowest in the afternoon at $1400 \mathrm{~h}$. It should be noted that the $\mathrm{RH}$ values recorded during this study are slightly higher than typical humidity levels in southern Arizona for most of the year. However, higher humidity levels are consistent with the Arizona monsoon that occurs from July to September and is characterized by large-scale shifts in wind and rainfall, which can be unpredictable. No precipitation occurred during the present study.

The difference between the mean 24-h CBT recorded in cows in the 2 treatments appears to be associated with the improved cooling capacity of FLFN technology, which is able to continuously cool cows under shade throughout the day. This is primarily a result of a more desirable microclimate provided for cows by the FLFN system observed in experiment 2. Peak CBT occurred in both treatments at $0800 \mathrm{~h}, 7 \mathrm{~h}$ after the cooling systems were turned off and $30 \mathrm{~min}$ before the systems being turned on. The rapid CBT increase from 0600 to $0800 \mathrm{~h}$ is consistent with sunrise, which occurred just before $0600 \mathrm{~h}$ each morning. Furthermore, the cows were in head locks at the feedline for daily inspection, and thus, prevented from entering the shade during this time. The solar heat load from direct sunlight likely plays a large role in the dramatic CBT increase during this time period. This increase further emphasizes the importance of shade access and operating a cooling system continuously, even during cooler times of day. Ortiz et al. (2010a) reported that reducing Korral Kool system (Korral Kool Inc.) operating time from 24 to $21 \mathrm{~h} / \mathrm{d}$ resulted in a higher CBT for multiparous cows. Moreover, the results of the present study support previous studies demonstrating the importance of shade access in addition to fan and mister cooling (Igono et al., 1987; Correa-Calderon et al., 2004).

That CBT tended to decrease following milking times strongly suggests cooling the holding pens in addition to the cooling effect of removing milk helped cows to dissipate heat, which is in agreement with previous studies (Araki et al., 1984; Ortiz et al., 2010a). The differences in CBT between treatments were reduced during these times, indicating the effects produced by the cooling system treatments were diminished when cows passed through the parlors. Additionally, feedline soakers were operated once cows returned from the parlors to their respective pens, further driving reductions in CBT.

The CBT increase that occurred in the afternoon demonstrates that the extreme ambient conditions had a direct effect on thermoregulation. The increase in CBT during this time suggests that neither cooling sys- 

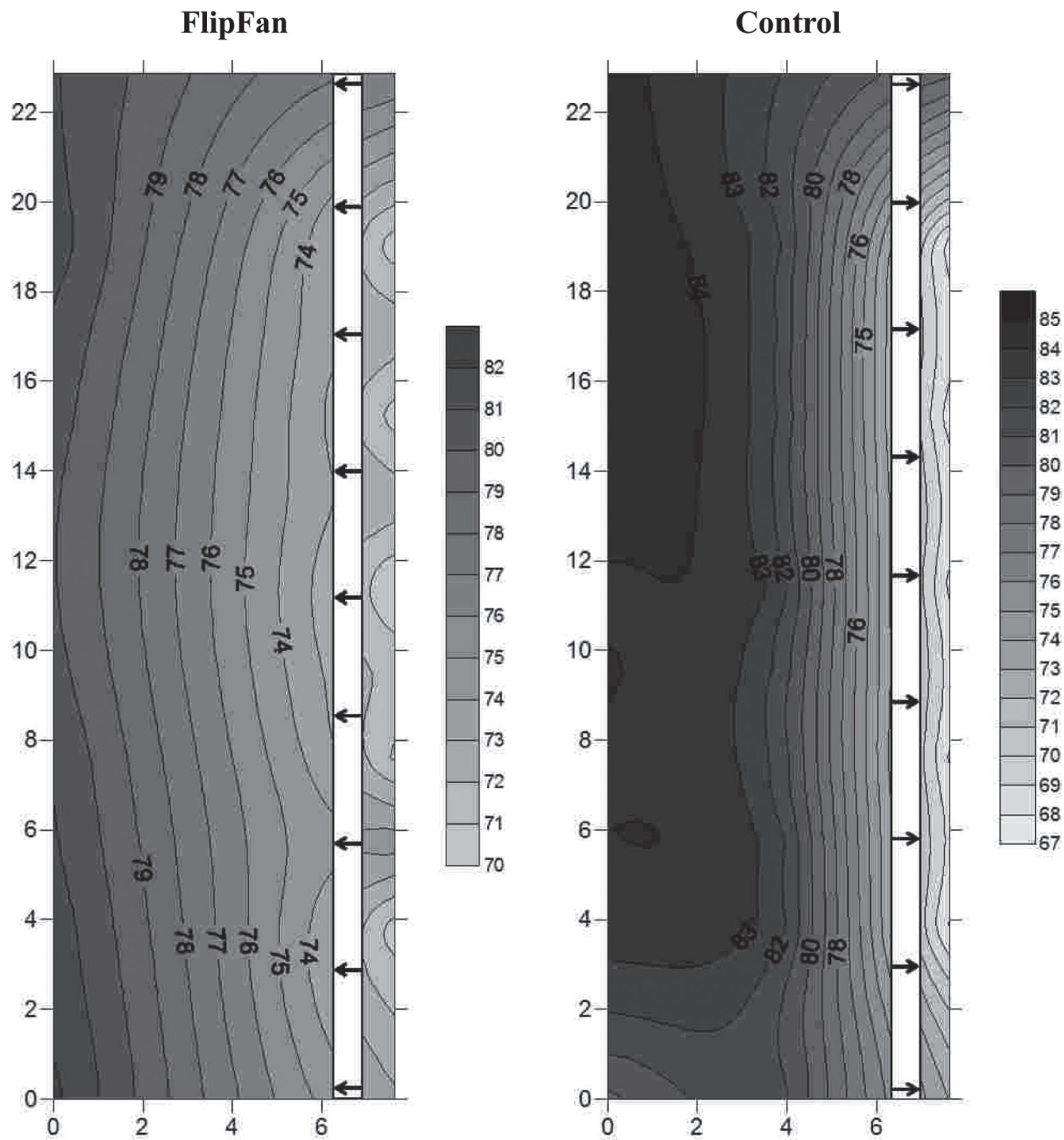

Figure 6. Isothermal maps representing mean temperature-humidity index of the shaded area of pens cooled by stationary fans and misters or the FlipFan Dairy Cooling System (Schaefer Ventilation Equipment, Sauk Rapids, MN) in the morning (1000-1200 h). Arrows denote fan and mister position and direction of cooling.

tem was fully capable of eliminating heat stress at the highest environmental temperatures recorded during the study. Although cows were still subjected to some degree of heat stress regardless of cooling treatment, the total heat load to which cows in the FLFN treatment group were exposed was reduced, as presented in experiment 2. This resulted in lower CBT in cows in this group. Further studies are warranted to determine if this equates to differences in production and reproduction. The fact that average $\mathrm{CBT}$ also increased immediately after the cooling systems were turned off indicates the potential benefit of operating a cooling system at lower temperatures. Previous work has shown that dairy cattle benefit from cooling at temperatures as low as $23^{\circ} \mathrm{C}$ ( $\mathrm{THI}=69$; Kendall et al., 2007). In addition, under these test conditions, a possible carryover effect occurred: cows with lower CBT during warmer times of day more readily restored normal CBT during cooler times of day without the assistance of cooling systems. Collier et al. (1981) concluded that a cow with access to shade would be able to maintain a lower CBT as a result of reduced solar heat load, whereas a cow without shade access would be forced to store heat until the cooler nighttime hours. It also appears that cows began to stand up after the cooling systems were turned off at night. We therefore recommend that stud- 
FlipFan

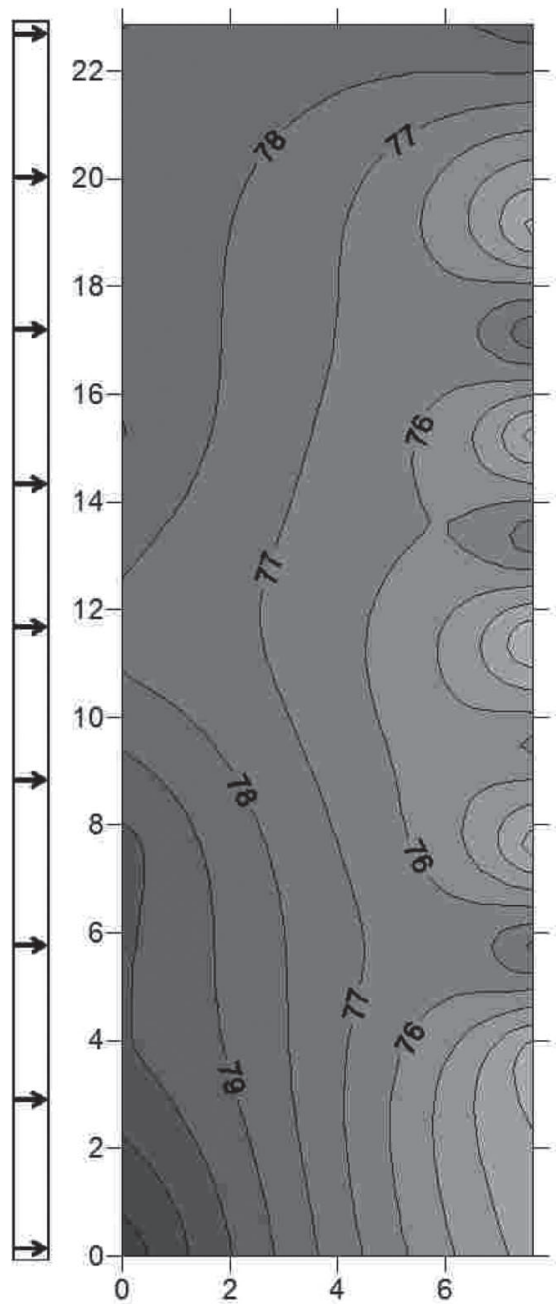

Control

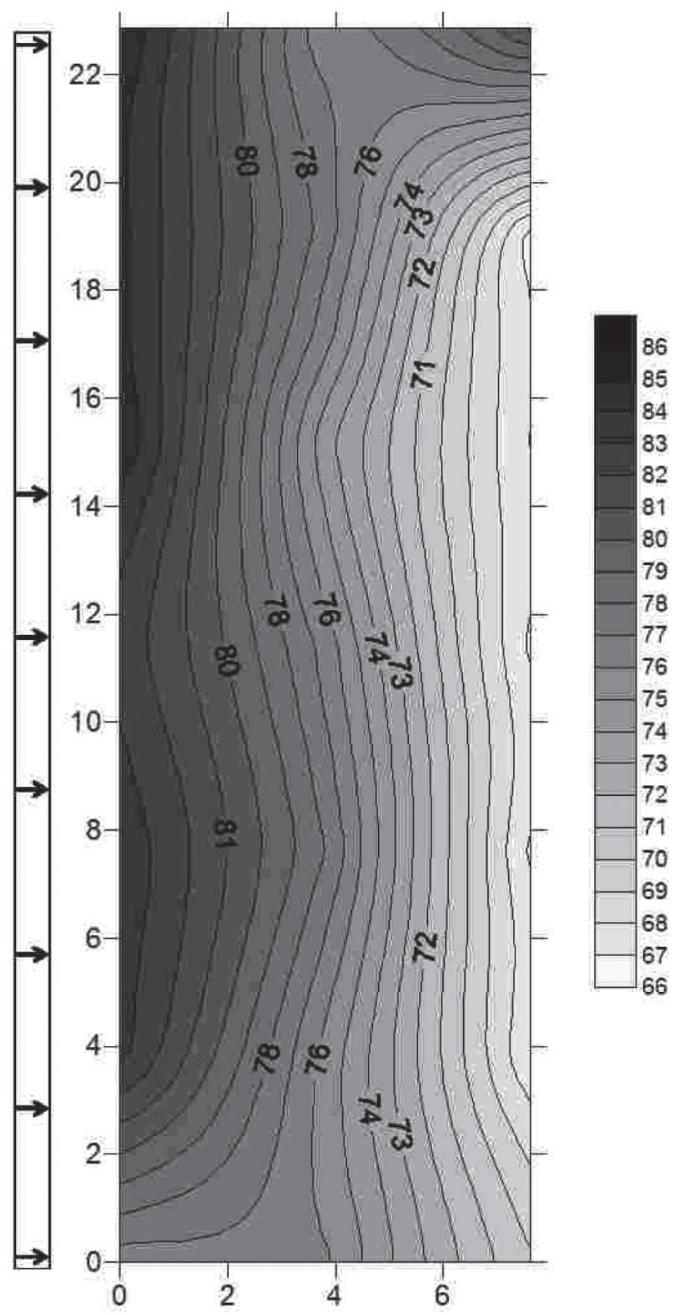

Figure 7. Isothermal maps representing mean temperature-humidity index of the shaded area of pens cooled by stationary fans and misters or the FlipFan Dairy Cooling System (Schaefer Ventilation Equipment, Sauk Rapids, MN) in the afternoon (1400-1600 h). Arrows denote fan and mister position and direction of cooling.

ies be conducted evaluating the cost or return of use of cooling systems as long as environmental conditions are outside of the thermoneutral zone for lactating dairy cows.

The negative effects of elevated CBT on milk production and reproduction performance have been quantified in the literature. Igono et al. (1985) reported that a cow with a mean rectal temperature of $39.1^{\circ} \mathrm{C}$ produced $0.7 \mathrm{~kg} / \mathrm{d}$ less milk than a cow with a rectal temperature of $38.8^{\circ} \mathrm{C}$. Zimbelman et al. (2009) also reported a negative relationship between rectal temperature and milk production. Previous research has also indicated that an increase in rectal temperature of $1^{\circ} \mathrm{C} 12 \mathrm{~h}$ after insemination decreased pregnancy rates from 61 to 45\% (Ulberg and Burfening, 1967). Furthermore, an increase in uterine temperature of $0.5^{\circ} \mathrm{C}$ on the day of or the day after insemination resulted in decreased conception rates of 13 and 7\%, respectively (Gwazdauskas et al., 1973). More recently, Hansen et al. (2001) concluded that an increase in CBT of approximately $1^{\circ} \mathrm{C}$ or greater can result in compromised oocyte function. Finally, cooling methods have been shown to improve reproductive efficiency, but most do not maintain CBT $<39^{\circ} \mathrm{C}$, meaning that depressed fertility during periods of heat stress should be expected despite supplemental cooling (Jordan, 2003).

Previous versions of shade-tracking technology relied on oscillating fans, which was limited by the amount of time a cow would spend in the zone of cooling. Conversely, cows can receive maximum cooling benefits with the FLFN system. In the morning, cows cooled by FLFN did not have to choose between shade and fan 

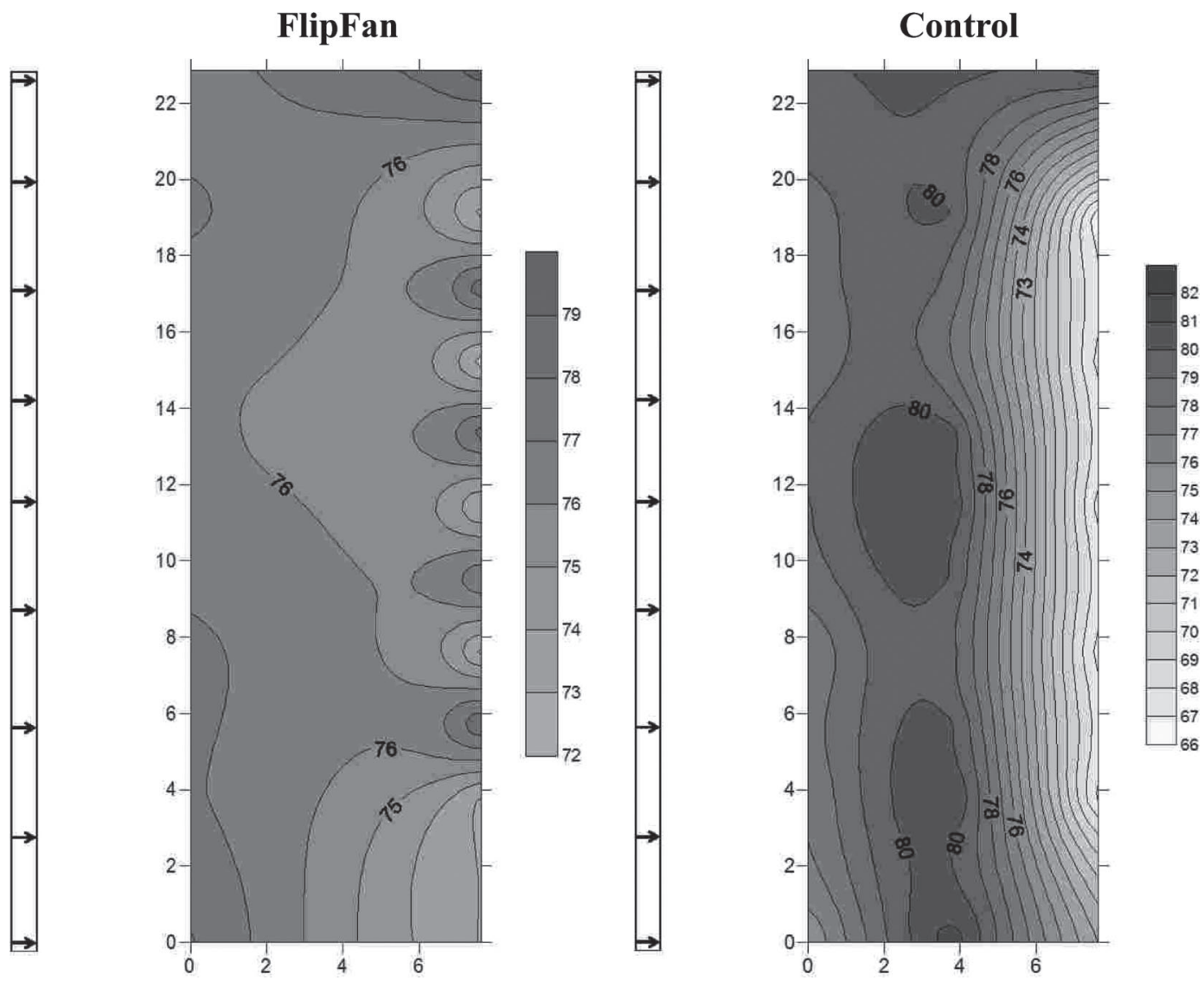

Figure 8. Isothermal maps representing mean temperature-humidity index of the shaded area of pens cooled by stationary fans and misters or the FlipFan Dairy Cooling System (Schaefer Ventilation Equipment, Sauk Rapids, MN) in the evening (1800-2000 h). Arrows denote fan and mister position and direction of cooling.

cooling. Cows cooled by the CTRL system, however, were forced to choose between shade and cooling. As Schütz et al. (2011) reported, cows prefer shade over sprinklers or ambient conditions. Furthermore, this preference becomes more significant as ambient temperature increases, even though sprinklers are more effective at reducing CBT through direct convective heat transfer to water combined with evaporative cooling. Tucker et al. (2008) also reported a direct relationship between solar radiation and shade use. Similar behavior was observed in the present study, in which cows cooled by CTRL remained in the shade even after the cooling system was turned on in the morning. Therefore, it seems trivial to operate stationary cooling systems in the morning, when cows are not taking advantage of the benefits. Furthermore, it is neither economical to incur additional operation costs nor environmentally friendly to consume water and energy resources during this period.

Estimates of lying time for dairy cows under thermoneutral conditions were not possible to estimate in this study, as the cows were never inside the thermoneutral zone for a 24-h period. However, it was clear that cows cooled by FLFN spent more time lying down compared with those in CTRL. This is the first study to illustrate that heat abatement influences daily (24-h) lying time in dairy cows. Previous work had illustrated that lying time declined in response to warmer ambient conditions, but had found no change associated with shade provision or feedline soakers. These other experiments had only explored a single method of cooling (e.g., shade; Kendall et al., 2006; Tucker et al., 2008; or sprinklers; J. M. Chen and C. B. Tucker, University of California; K. E. Schutz, AgResearch Ltd., New Zealand; unpublished data), thus the current difference in lying time could be the result of a more effective combination of cooling strategies, including shade, fans, and misters.

Cows cooled by FLFN also had more lying bouts per day than CTRL cows. Furthermore, increased lying bouts in FLFN cows may explain, in part, the observation of increased daily lying time compared to CTRL. This pattern has been reported when cows have more comfortable lying surfaces (Tucker and Weary, 2004). Indeed, the dirt surface temperature in the FLFN was 


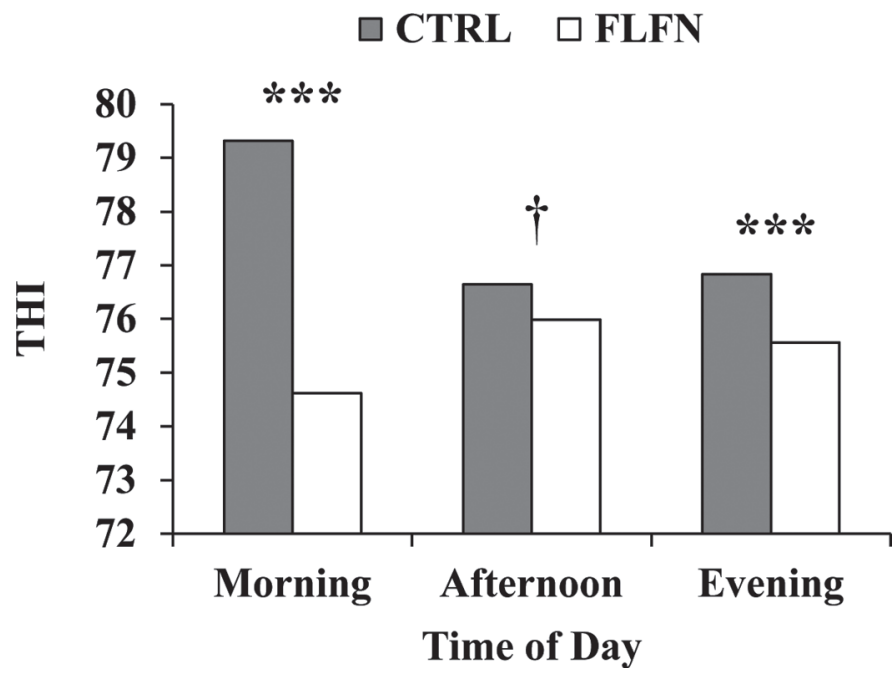

Figure 9. Mean temperature-humidity index (THI) of area in shadow cast by a shade structure equipped either stationary fans and misters (CTRL) or the adjustable FlipFan Dairy Cooling System (FLFN; Schaefer Ventilation Equipment, Sauk Rapids, MN) at different times of day. Morning (1000-1200 h), afternoon (1400-1600 h), and evening (1800-2000 h) represent the 2-h window during which ambient temperature and relative humidity at 5 -min intervals was used to calculate THI. Treatment by period interaction $=\dagger P<0.10,{ }^{* * *} P<$ 0.001 ; pooled $\mathrm{SEM}=0.24$.

likely cooler, and thus more comfortable than in CTRL, based on the microclimate information measured in experiment 2. Moreover, cows cooled by the FLFN system may have changed position more frequently to follow the shade, fans, and misters as they rotated throughout the day.

As previously mentioned, the effects that CBT and resting behavior have on milk production were not analyzed due to the short duration of the present study, because an approximately 2-d lag of environmental effects on cow performance exists (West, 2003; Spiers et al., 2004). Therefore, observations of milk production would not adequately reflect the effects of the environmental conditions to which cows were exposed during the present study. Previous research suggests, however, that heat abatement results in increased milk production. Direct measurements of milk production and reproductive performance should provide more insight on the economic benefit of implementing an adjustable fan and mister system over a stationary one. A prolonged study would allow direct measurements of cow performance and provide further insight on the economic benefits of implementing FLFN on a dairy.

The mapping experiment was valuable in providing an explanation for the differences observed in the CBT and lying behavior of cows in each cooling treatment. The FLFN system had the greatest advantage during the morning hours when the fans were positioned to face westward, where the cows congregated in the shade to reduce exposure to solar heat load, based on anecdotal evidence. Although few differences were observed between the cooling systems during the midafternoon heat, the FLFN system provided more uniform cooling because the fans were able to make subtle adjustments to compensate for changes in wind speed and direction, allowing the cooled air current to flow in the direction of the cows. The uniform cooling enables cows to spread out over the shaded area rather than compete for limited cooler space. The FLFN system also had a slight advantage over the stationary fan system in that its fans continued to be able to reach the shade as it migrated further from the shade structure later in the evening. Whereas the FLFN system was successful at significantly reducing the THI of the shaded area, compared with the CTRL system, further improvements are required to cool the microenvironment below a THI of 68 .

The coolest regions of the isothermal maps are generally located on the eastern edge of the shadow. This phenomenon is likely due to prevailing west winds and the direction of fan pushing cooler air in an easterly direction. Evaporation of mist particles in this region of the shade will also contribute to the cooling effect of the microclimate.

\section{CONCLUSIONS}

The FlipFan Dairy Cooling System decreased CBT and increased lying time and number of lying bouts of lactating dairy cows in a semiarid climate compared with cows housed under a stationary fan and mister system. Furthermore, the FlipFan system combined with shade created a cooler and more uniform microclimate compared with conventional and stationary fans, misters, and shade. These results indicate that the FlipFan system provides more effective heat abatement than traditional methods. Further work, including quantification of financial implications and optimization of when to use these systems, is needed.

\section{ACKNOWLEDGMENTS}

The authors acknowledge Mike and Nick Terrell (Advanced Dairy Systems) for technical support and Nick and Larry Vanderwey of Grand View Dairy (Buckeye, AZ) for use of farm and cows. We also acknowledge Eranda Rajapaksha (University of California, Davis) for providing technical assistance with lying behavior measurements.

\section{REFERENCES}

Araki, C. T., R. M. Nakamura, L. W. G. Kam, and N. Clarke. 1984. Effect of lactation on diurnal temperature patterns of dairy cattle in hot environments. J. Dairy Sci. 67:1752-1760. 
Armstrong, D. V. 1994. Heat stress interaction with shade and cooling. J. Dairy Sci. 77:2044-2050.

Brown-Brandl, T. M., R. A. Eigenberg, J. A. Nienaber, and G. L. Hahn. 2005. Dynamic response indicators of heat stress in shaded and non-shaded feedlot cattle. Part 1: Analyses of indicators. Biosystems Eng. 90:451-462.

Buffington, D. E., A. Collazo-Arocho, G. H. Canton, D. Pitt, W. W. Thatcher, and R. J. Collier. 1981. Black globe-humidity index (BGHI) as comfort equation for dairy cows. Trans. Am. Soc. Agric. Eng. 24:711-714.

Collier, R. J., R. M. Eley, A. K. Sharma, R. M. Pereira, and D. E. Buffington. 1981. Shade management in subtropical environment for milk yield and composition in Holstein and Jersey cows. J. Dairy Sci. 64:844-849

Collier, R. J., C. M. Stiening, B. C. Pollard, M. J. VanBaale, L. H. Baumgard, P. C. Gentry, and P. M. Coussens. 2006. Use of gene expression microarrays for evaluating environmental stress tolerance at the cellular level in cattle. J. Anim. Sci. 84:E1.

Correa-Calderon, A., D. V. Armstrong, D. Ray, S. DeNise, M. Enns, and C. Howison. 2004. Thermoregulatory responses of Holstein and Brown Swiss heat-stressed dairy cows to two different cooling systems. Int. J. Biometeorol. 48:142-148. http://dx.doi. org/10.1007/s00484-003-0194-y.

Gwazdauskas, F. C., W. W. Thatcher, and C. J. Wilcox. 1973. Physiological, environmental, and hormonal factors at insemination which may affect conception. J. Dairy Sci. 56:873-877.

Hansen, P. J., M. Drost, R. M. Rivera, F. F. Paula-Lopes, Y. M. AlKatanani, C. E. Krininger III, and C. C. Chase Jr. 2001. Adverse impact of heat stress on embryo production: Causes and strategies for mitigation. Theriogenology 55:91-103.

Hillman, P. E., C. N. Lee, and S. T. Willard. 2005. Thermoregulatory responses associated with lying and standing in heat-stressed dairy cows. Trans. Am. Soc. Agric. Eng. 48:795-801.

Igono, M. O., H. D. Johnson, B. J. Steevens, G. F. Krause, and M. D. Shanklin. 1987. Physiological, productive, and economic benefits of shade, spray, and fan system versus shade for Holstein cows during summer heat. J. Dairy Sci. 70:1069-1079.

Igono, M. O., B. J. Steevens, M. D. Shanklin, and H. D. Johnson. 1985. Spray cooling effects on milk production, milk, and rectal temperatures of cows during a moderate summer season. J. Dairy Sci. 68:979-985.

Jensen, M. B., L. J. Pedersen, and L. Munksgaard. 2005. The effect of reward duration on demand functions for rest in dairy heifers and lying requirements as measured by demand functions. Appl. Anim. Behav. Sci. 90:207-217.

Jordan, E. R. 2003. Effects of heat stress on reproduction. J. Dairy Sci. 86(E. Suppl.):E104-E114.

Kadzere, C. T., M. R. Murphy, N. Silanikove, and E. Maltz. 2002. Heat stress in lactating dairy cows: A review. Livest. Prod. Sci. 77:59-91.

Kendall, P. E., P. P. Nielsen, J. R. Webster, G. A. Verkerk, R. P. Littlejohn, and L. R. Matthews. 2006. The effects of providing shade to lactating cows in a temperate climate. Livest. Sci. 103:148-157.

Kendall, P. E., G. A. Verkerk, J. R. Webster, and C. B. Tucker. 2007. Sprinklers and shade cool cows and reduce insect-avoidance behavior in pasture-based dairy systems. J. Dairy Sci. 90:3671-3680.

Ledgerwood, D. N., C. Winckler, and C. B. Tucker. 2010. Evaluation of data loggers, sampling intervals, and editing techniques for measuring the lying behavior of dairy cattle. J. Dairy Sci. 93:5129-5139. http://dx.doi.org/10.3168/jds.2009-2945.

Mitlöhner, F. M., J. L. Morrow, J. W. Dailey, S. C. Wilson, M. L. Galyean, M. F. Miller, and J. J. McGlone. 2001. Shade and water misting effects on behavior, physiology, performance, and carcass traits of heat-stressed feedlot cattle. J. Anim Sci. 79:2327-2335.

Ortiz, X. A., J. F. Smith, B. J. Bradford, J. P. Harner, and A. Oddy. 2010a. Effects of running time of a cattle-cooling system on core body temperature of cows on dairy farms in an arid environment. J. Dairy Sci. 93:4949-4954. http://dx.doi.org/10.3168/jds.20103119

Ortiz, X. A., J. F. Smith, B. J. Bradford, J. P. Harner, and A. Oddy. 2010b. A comparison of the effects of 2 cattle-cooling systems on dairy cows in a desert environment. J. Dairy Sci. 93:4955-4960. http://dx.doi.org/10.3168/jds.2010-3127.

Ortiz, X. A., J. F. Smith, B. J. Bradford, J. P. Harner, and A. Oddy. 2011. Effect of complementation of cattle cooling systems with feedline soakers on lactating dairy cows in a desert environment. J. Dairy Sci. 94:1026-1031. http://dx.doi.org/10.3168/jds.20103126

Purwanto, B. P., Y. Abo, R. Sakamoto, F. Furumoto, and S. Yamamoto. 1990. Diurnal patterns of heat production and heart rate under thermoneutral conditions in Holstein Friesian cows differing in milk production. J. Agric. Sci. (Camb.) 114:139-142.

Reich, L. J., D. M. Weary, D. M. Veira, and M. A. G. von Keyserlingk. 2010. Effects of sawdust bedding dry matter on lying behavior of dairy cows: A dose-dependent response. J. Dairy Sci. 93:1561-1565.

Rhoads, M. L., R. P. Rhoads, M. J. VanBaale, R. J. Collier, S. R. Sanders, W. J. Weber, B. A. Crooker, and L. H. Baumgard. 2009. Effects of heat stress and plane of nutrition on lactating Holstein cows: I. Production, metabolism, and aspects of circulating somatotropin. J. Dairy Sci. 92:1986-1997. http://dx.doi. org $/ 10.3168 /$ jds.2008-1641.

Roman-Ponce, H., W. W. Thatcher, D. E. Buffington, C. J. Wilcox, and H. H. Van Horn. 1977. Physiological and production responses of dairy cattle to a shade structure in a subtropical environment. J. Dairy Sci. 60:424-430.

Schütz, K. E., A. R. Rogers, N. R. Cox, J. R. Webster, and C. B. Tucker. 2011. Dairy cattle prefer shade over sprinklers: Effects on behavior and physiology. J. Dairy Sci. 94:273-283. http://dx.doi org/10.3168/jds.2010-3608.

Schütz, K. E., A. R. Rogers, Y. A. Poulouin, N. R. Cox, and C. B. Tucker. 2010. The amount of shade influences the behavior and physiology of dairy cattle. J. Dairy Sci. 93:125-133. http:// dx.doi.org/10.3168/jds.2009-2416.

Spiers, D. E., J. N. Spain, J. D. Sampson, and R. P. Rhoads. 2004. Use of physiological parameters to predict milk yield and feed intake in heat-stressed dairy cows. J. Therm. Biol. 29:759-764.

St-Pierre, N. R., B. Cobanov, and G. Schnitkey. 2003. Economic losses from heat stress by US livestock industries. J. Dairy Sci. 86(E. Suppl.):E52-E77.

Tucker, C. B., A. R. Rogers, and K. E. Schütz. 2008. Effect of solar radiation on dairy cattle behavior, use of shade and body temperature in a pasture-based system. Appl. Anim. Behav. Sci. 109:141154. http://dx.doi.org/10.1016/j.applanim.2007.03.015.

Tucker, C. B., and D. M. Weary. 2004. Bedding on geotextile mattresses: How much is needed to improve cow comfort? J. Dairy Sci. 87:2889-2895.

Ulberg, L. C., and P. J. Burfening. 1967. Embryo death resulting from adverse environment on spermatozoa or ova. J. Anim. Sci. 26:571-577.

West, J. W. 2003. Effects of heat-stress on production in dairy cattle. J. Dairy Sci. 86:2131-2144.

Zähner, M., L. Schrader, R. Hauser, M. Keck, W. Langhans, and B. Wechsler. 2004. The influence of climatic conditions on physiological and behavioural parameters in dairy cows kept in open stables. J. Anim. Sci. 78:139-147.

Zimbelman, R. B., R. P. Rhoads, M. L. Rhoads, G. C. Duff, L. H. Baumgard, and R. J. Collier. 2009. A re-evaluation of the impact of temperature humidity index (THI) and black globe humidity index (BGHI) on milk production in high producing dairy cows. Pages 158-168 in Proc. Southwest Nutr. Manag. Conf. Tempe, AZ ARPAS, Savoy, IL. 